\title{
PECULIARITIES OF DIGISEXUALITY AMONG MODERN UKRAINIAN MEN
}

\section{Zhydko M. E.}

\section{INTRODUCTION}

According to R. Kurzweil law of accelerating returns, the development of technologies happens exponentially. Many experts predicted that most likely under 2030-2045 it would lead to the moment of technological singularity, the historical point in the development of civilization after which the technical progress would be fast, complex and inaccessible for understanding. Even today one can observe that rather radical changes in the mental functioning of a man (specific violations of cognitive processes, emotions, mechanisms of self-regulation, axiological sphere of personality, relationship) are associated with the exponential development of technologies, united by the general notion of digital dementia ${ }^{1}$. Researchers studying the impact of the digital world on the human psyche, refer to the significant differences between generations of "digital from birth" and "digital migrants"2. This inevitably influences the sphere of sexual relations, transforming it into a fairly new phenomenology of digisexuality ${ }^{3}$. One of the most famous and studied phenomena is the decline in traditional (from here on out we will use biosociopsychological characteristic for it) sexual activity of men. Thus, the research in National Opinion Research Center (NORC) at the University of Chicago noted American young men with less sexual activity ${ }^{4}$. Since 1972, the General Social Survey has been monitoring data about several thousand people. It was revealed that $23 \%$ of adults had no sex in the previous year (this number doubled in the last 10 years) and the

\footnotetext{
${ }^{1}$ Стрельникова Л. Цифровое слабоумие. Химия и жизнь. 2014. № 12. URL: https://www.hij.ru/read/articles/view/5210/

${ }^{2}$ Смолл Г., Ворган Г. Мозг он-лайн. Человек в эпоху Интернета. Москва: КоЛибри, 2011. 352 с.

${ }^{3}$ Пази М. Цифровая любовь. «Русский репортер» 2019. № 3 (467) URL: https://expert.ru/russian_reporter/2019/03/tsifrovaya-lyubov/

${ }^{4}$ Seks-kileri: shcho "vbivae" bazhannya u molodih cholovikiv // BBC News /Ukraine from 01.05.2019. Available at: https://www.bbc.com/ukrainian/features-48020711
} 
number of men among them was "much more than expected". The study showed that the proportion of men under the age of 30 who had no sex in the past year has tripled to $28 \%$ since 2008 (it is much higher than the growth rate among women of the same age group - 8\%). Data from personal interviews also showed that more than half of American adults aged 18 to $34(51 \%)$ did not have a permanent partner (33\% in 2004). However, S. Forrest (Institute for Health and Society, Newcastle University) told BBC Three that although the US analysis was reliable and based on a large set of data, this did not necessarily indicate a similar trend among the inhabitants of Albion. "I'm not sure that we can talk about a similar trend in the UK. At least, it is true according to the National Survey of Sexual Attitudes and Lifestyles (NATSAL) held every ten years. But by 2020, we will get the results of another study, so we are curious if the US experience will be reflected in the future of our country". Even nowadays, there is geography of digisexuality ${ }^{5}$. Due to the fact that Ukraine more recently joined the global digital world, domestic research on digital dementia is almost non-existent; research in digisexuality (with the exception of juridical, religious and cinematic aspects ${ }^{6}$ ) is absent. Meanwhile, psychotherapeutic practice shows that despite the liberalization of attitudes towards atypical sexual practices and the growth of various opportunities for sexual contacts in Ukraine there is a similar decrease in sexual activity.

The purpose of our analysis is to study the porno content used by Ukrainian men because pornography (especially on-line) ${ }^{7}$ is one of the main "killers" of male sexuality and men in connection with rather strong masculine stereotypes form the most closed research group ${ }^{8}$.

Given the pornography as a rather new field for domestic psychological research, we consider it necessary to bring psychological differentiation of erotica and pornography. Erotica in the broadest sense

${ }^{5}$ Nash, Catherine, Gorman-Murray, Andrew (Eds.) The Geographies of Digital Sexuality Palgrave. Macmillan, 2019. XV, p. 286.

6 Право, релігія, кіно / Д. О. Вовк та ін. ; за заг. ред.: Д. О. Вовк, О. П. Свсєєва. Харків: ТОВ «Видавництво „Права людини“», 2018. 184 с.

${ }^{7}$ Зимбардо Ф., Коломбе Н. Мужчина в отрыве: игры, порно и потеря идентичности. Москва: Альпина Паблишер, 2017. 344 с.

${ }^{8}$ Maltz W., Maltz L. The Porn Trap: The Essential Guide to Overcoming Problems Caused by Pornography. HarperCollins, New York. 2008.

${ }^{9}$ Spink A., Jansen B.J. Web Search: Public Searching of the Web. Berlin: SpringerVerlag, 2004. 
of the term is commonly referred to as all sexual feelings, fantasies and experiences, as well as stimuli (visual, audiological, kinesthetic, olfactory, taste, etc.) that cause them. Traditionally erotic materials differ on the following grounds: 1) content, that is, what exactly sexual needs or actions they satisfy, stimulate or depict (hetero- or homosexual, sadomasochistic, etc.); 2) the degree of their frankness and detalization (the so-called rigid erotica includes a detailed image of the genitals or sexual intercourse, whereas soft erotica tempts and hints at sexual acts more than shows them); 3) ethical and aesthetic level. In addition, the difference between erotica and pornography always depends on the cultural-historical context and the level of personal development of the subject.

Table 1 demonstrates generalized differential and diagnostic criteria for the delimitation of erotica and pornography highlighted in one of our previous works ${ }^{9}$.

Table 1

Differential and diagnostic criteria of psychological differences between erotica and pornography

\begin{tabular}{|l|l|}
\hline \multicolumn{1}{|c|}{ Erotica } & \multicolumn{1}{c|}{ Pornography } \\
\hline $\begin{array}{l}\text { Syncretically, holistically depicts a } \\
\text { man in complete diversity and } \\
\text { richness of his experiences }\end{array}$ & $\begin{array}{l}\text { Analytical, fixes attention on } \\
\text { certain points of gender relations, } \\
\text { taking them out of the living } \\
\text { context and reducing sexuality to } \\
\text { coitus and its technique }\end{array}$ \\
\hline $\begin{array}{l}\text { Non-utilitarian, self-worth } \\
\text { exploring of human world, opening } \\
\text { new dimension in it }\end{array}$ & $\begin{array}{l}\text { Rigidly functional, causes } \\
\text { predetermined specific reactions }\end{array}$ \\
\hline $\begin{array}{l}\text { Individual and unique both in } \\
\text { subject and in execution }\end{array}$ & $\begin{array}{l}\text { Dealing with de-individualized, } \\
\text { massive standards and stereotypes }\end{array}$ \\
\hline $\begin{array}{l}\text { Builds its world according to laws } \\
\text { of aesthetics, inspires sexuality }\end{array}$ & $\begin{array}{l}\text { Makes everything about } \\
\text { physiology, dehumanizing man and } \\
\text { his world }\end{array}$ \\
\hline $\begin{array}{l}\text { Often violates usual norms of } \\
\text { decency for and because of the fact }\end{array}$ & $\begin{array}{l}\text { Violations of social conventions - } \\
\text { an end in itself; it destroys the ban }\end{array}$ \\
\hline
\end{tabular}

${ }^{9}$ Кочарян А.С., Жидко М.Е. Психосексуальное развитие человека. Формирование мужского гендера. Харьков. НАУ «ХАИ», 2005. 91 с. 


\begin{tabular}{|l|l|}
\hline \multicolumn{1}{|c|}{ Erotica } & \multicolumn{1}{c|}{ Pornography } \\
\hline $\begin{array}{l}\text { that opens new depths of human } \\
\text { existence, not yet understood and } \\
\text { not accepted by mass } \\
\text { consciousness }\end{array}$ & $\begin{array}{l}\text { and moreover speculates on the } \\
\text { lack of novelty }\end{array}$ \\
\hline $\begin{array}{l}\text { Bears ethical values and violates } \\
\text { the rules of public morality }\end{array}$ & $\begin{array}{l}\text { Denies both moral and morality, } \\
\text { making a person the object of } \\
\text { commercial or ideological } \\
\text { manipulation }\end{array}$ \\
\hline Means of free self-expression & $\begin{array}{l}\text { Part of the entertainment industry, } \\
\text { production, aimed at profit making }\end{array}$ \\
\hline
\end{tabular}

However, one should take into account that we still have no unambiguous and / or validated scientific point of view on the effects of erotic materials on sexual behavior. Yes, there exist three theories about such influence. First, the theory of imitation, argues that the demonstration of emotionally attractive and exciting sexual patterns provokes inheritance, thereby increases the likelihood in spread of such behavior. The theory of catharsis, by contrast, believes that erotic materials act as protector, allowing a person to defuse the depressed sexual desire and thus reducing the likelihood of the implementation of socially unacceptable desires. Zero theory believes that sexual behavior of an individual develops in his own script and depends little on external influences, so erotic materials play a secondary role. The following data traditionally serve as sources for validation of every theory: 1) social statistics about change in sexual behavior of people, and especially the dynamics of sexual crimes in those countries where the prohibition of pornography has been abolished; 2) criminological data about people who committed certain sexual crimes; 3) statistics about lovers and intensive consumers of commercial erotica and pornography; 4) experimental psychological studies which check the direct influence of certain sexually-erotic materials on the settings and behavior of the subjects. However, none of these sources alone is sufficient.

In addition, it must be taken into account that erotica and pornography are traditionally marginal social and psychological phenomena. S. Cohen writes: "Societies are prone to periods of moral panic now and then. Some circumstances, phenomenon, person or group of people start to be considered threatening for common social values 
and interests; the media depicts them in a stylized and stereotyped way; moral barricades are filled by publishers, bishops, politicians and other faithful people; officially recognized experts announce diagnoses and recommendations; special means of combat are produced or more often used; after that the phenomenon disappears, suppresses or worsens ... The panic may decrease or it can be forgotten, but sometimes it has serious and long-lasting consequences to cause changes in legal and social policy, or even in the way societies consider themselves". To have the next wave of moral panic emerged, three conditions are needed: 1) the situation of social crisis; 2) a social group or organization ready and able to provoke public indignation and direct it to the desired address; 3) stigmatized groups or phenomena that can be easily turned into scapegoat.

In our view, all these conditions have been created in Ukrainian society (primarily due to the hybrid war and radical nationalist groups) to stimulate further shift in male sexuality to the digital area. Analyzing the structure of pornographic content we can detect not only cultural taboo areas but also those unconscious conflicts that occur in non-digital sexuality.

\section{Digital dependence and digisexuality}

The concept of digisexuality (digisexuals) was proposed for the first time in 2016 in the article by the director of the Center for Professional and Applied Ethics at the University of Manitoba in Winnipeg (Canada), assistant professor Nile MacArthur in the Journal of Sexual and Relationship Therapy. Investigating the immediate implications of the introduction for immersive technologies (that is, those that provide the effect of full presence in the virtual environment) he invoked in this concept a new sexual identity associated with the use for sexual interactions (both between people and between man and various products of artificial intellect, for example, sex androids) of digital technology. His quotation was widespread in the media of the postSoviet informational space. According to it "one can confidently say that the era of three-dimensional virtual sex has come. As these technologies evolve, their use will grow and a lot of people start to identify themselves as "digisexuals" - those whose main sexual identity is perceived through the use of technology ... Many of them will realize that the experience with this technology will become an integral part of 
the sexual identity, and some will prefer it over direct sexual intercourse with people" ${ }^{\prime 10}$.

Another expert, assistant professor at University of Wisconsin-Stout (USA) Markie Twist has identified two waves of digisexuality. "The first wave prefers sex through technology, but with the participation of live people: online pornography, sexting, etc. I would say that the second wave of digisexuals will choose immersive sexual encounters, partners like sex-bots and sex in virtual reality "11.

Famous British futurist I. Pearson is convinced that over the next decade, the majority of the population in developed countries will initiate the process of replacing "live" sexual partners with artificial ones. According to his forecasts, by 2030, almost every mature inhabitant of the Earth will have some form of experience in digital sex, and by 2035 "smart" digital-sex "toys" will be found in most homes. The main motivators of such changes will be comfort and pleasure: thanks to more functional than the human brain, artificial intelligence, sex androids will be able to offer the consumer a "personality that can be customized with the emotional luggage he wants," and therefore sex with a digital-robot "will become easier, safer, more frequent and much more enjoyable". In 2017, the BBC Three created a documentary film "The Virtual Reality Virgin" which demonstrated the prototype of such an android. Matt McMullen, whose company is working on the creation of digisexual products, describes the advantages: "A customer can create a doll with some personality: depending on his wish it can be smart or not, shy or not "12. The Android Love Doll model has 50 sexy stories, and the Harmony doll from Abyss Creations is synchronized with an application that learns while communicating with the user. Over the next decade, the company hopes to launch a living version of its dolls on the market. So far, the natural limitation for the proliferation of digital-sex products is a fairly high price: today, moving and talking models cost about $\$ 20,000$, but eventually, technology will inevitably become

${ }^{10}$ Young S. Digisexuals: number of people who prefer sex with robots to surge, find experts / Independent, 30/10/2017. URL: https://www.independent.co.uk/life-style/ digisexuals-robot-sex-preferences-university-manitoba-canada-identity-a8084096.html

11 Журенков К. О дивный, новый секс! Цифросексуалы - кто они? Журнал «Огонек». 2017 № 51 C. 38. URL: https://www.kommersant.ru/doc/3501080

12 Курпатов А. Четвертая мировая война. Будущее уже рядом. Москва: Академия Смысла, 2018. 335 с. 
cheaper. For example, now it will cost you about \$10,000 to buy Frigid Farrah robot, which allows men to simulate rape. BMJ Sexual \& Reproductive Health magazine unveiled a British study that $40 \%$ of men were about to buy sex robot in the next five years, and $49 \%$ of men were ready to get involved with "hyper-realistic" sex doll.

David Linden, professor of neurobiology at Johns Hopkins University believes that "many people secretly love the idea of somehow being free from the constraint of needing another person to experience the heights of sexual excitement. But they shouldn't get their hopes up: The state of the art in erotic gadgetry is still very crude. [...] Sex robot of the future may have a form of a dense suit with its built-in blue LEDs. [...] Instead of using sensory organs naturally, as a sex robot would do, neural virtual reality will simulate this experience by artificially activating nerve cells"13. The porn industry is at the forefront of modern business (which is associated with high and fast revenues). So, the wellknown Japanese company has already created an appropriate "sex simulator", which consists of the Oculus Rift virtual reality shaft, a special fitting suit that stimulates the necessary areas and body parts, as well as an artificial female breasts with feedback and Tenga mechanical masturbator. The total price is about $\$ 400$.

Digisexism inevitably affects the transformation of marriage and family relations. The intimate space has changed significantly: dating occurs in specialized software applications ${ }^{14}$, married couples now share a bed with a variety of gadgets ${ }^{15}$. Gradually, digisexuality is being converted from a marginal phenomenon into one of the trend elements in mass culture. A popular science fiction book (which was quickly filmed) "She" tells about a lonely man falling in love with a digital intelligence while "Blade Runner 2049" talks about similar digital relations between the protagonist and machine intelligence. The less popular movie "Lars and the Real Girl" shows a man in love with a sex doll. A number of top serials somehow touch the topic of digisexuality: "Black Mirror," "The World of the Wild West," "Altered Carbon", "Love, Death and Robots" and so on. And according to media reports in April 2017 a Chinese

\footnotetext{
13 Линден Д. Мозг и удовольствия. Москва: Эксмо, 2012. 288 с.

${ }^{14}$ Калинина Е., Зонхоева Л. Секс будущего: что нас ждет в эпоху digital. URL: https://adindex.ru/publication/opinion/internet/2015/09/10/127814.phtml

15 Hafner K. Laptop slides into bed in love triangle. The New York Times. August 24, 2006.
} 
specialist in advanced technology Zhen Jiajia married a self-created woman-robot In-In.

Of all phenomena in digisexuality the most analyzed is the dependence on digital pornographic content which is probably due, firstly, to the first wave of digital secrecy, and, secondly, high Internet availability makes inevitable "sexually oriented" activity at work. The more time they spent on porn sites, the lower was productivity. This was evidenced by the 2006 study with over 3,400 volunteers ${ }^{16}$. It turned out that $41 \%$ of them were reprimanded for using a working computer not for work but pornography.

According to neurophysiological studies the images with sexual themes serve as a signal for the release of dopamine (similar to neurochemical processes in the brain of a drug addict who has just taken a dose of a psychoactive substance). Sexually addicted person is able to look half the night for content that does this way. The prefrontal cortex of such people is switched to the search, storage and extraction for information that can quell the insatiable brain and it always requires a new dose of dopamine ${ }^{17}$.

In this sense, the dependence on digital porn content is fixative but differs from sexual obsessions by the fact that instead of the process of imagination (which, due to the creativity and complexity of the problem, develops involuntarily and promotes the evolution of other cognitive functions) it uses ready-made artificial images and scripts generated by machine intelligence for individual customer queries based on analysis (which is not understood in many cases). To understand this one should refer to the sphere of male sexual fantasies.

\section{The sphere of male sexual fantasies}

The history of art shows that a person with an exceptional characteristic is able not only to respond to erotic images, but also to create them, embodying the imagination since ancient times. In some ways one can say that the ability to fantasize sexually is one of the highest functions a person has ever developed.

${ }^{16}$ Cooper A., Safir M. P., Rosenmann A. Workplace worries: A preliminary look at online sexual activities at the office - emerging issues for clinicians and employers. Cyberpsychology \& Behavior 2006: 9:22-29. 2011. $-352 \mathrm{p}$.

Smoll G., Vorgan G. Mozg on-lajn. Chelovek v epohu Interneta. - M.: KoLibri, 
As shown in our previous work ${ }^{18}$ sexual fantasies occupy a relatively large range on the general continuum of human dreams. The time people devote to such fantasies often exceeds the time allocated to other activities, and is characterized by the following dynamics: from the early childhood it is constantly increasing - in adolescents it is an average of $17 \%$ of the total time, aged 18 to For 20 years it reaches $20 \%$, and then falls to $8 \%$ between 28 and 35 years and up to $1 \%$ and less after 65 years. At the same time, the question about the effect in extent of hormonal shifts, the socio-sign influence of the environment and the psychodynamic processes occurring in these periods remains open.

Both men and women can combine sexual fantasies with different types of sexual activity. On this basis, there are masturbatory fantasies ( $71 \%$ men and $72 \%$ women), coital fantasies (30\% men and women), and, in fact, erotic fantasies.

Barkley's research has shown that female fantasies were mostly emotional, romantic, while female fantasies were similar to the content of pornographic books full of sexual details with a minimum of emotions. Crepo's later work demonstrated that sexual fantasies of women had, first and foremost, exhibitionist, narcissistic (when a woman imagines that she has a great sexual attractiveness), as well as masochistic nature (for example, that she is under aggression of one or more sexual partners).

Male range is much wider. Yes, they are characterized by fetishistic fantasies (associated with clothing and accessories for women) or fantasy of conquest (when the subject commands, seduces or forces someone to sexual intercourse). Men also have fantasies about partner substitution (when the subject represents an intercourse with a new partner, who can act as a former partner (an old friend or girlfriend) and simply a stranger to whom a desire arises, for example, celebrity, neighbor, relative, a teacher, a salesman, or just a fictional figure, an imaginary ideal), group sex, observation, and fantasies of orogenital (fealty, cunnilingus, or oral ejaculation) and initialization type (defilement of girls).

18 Жидко М. Е. Сексуальные фантазии: гендерные, возрастные особенности и их взаимосвязь с психосексуальным поведением. Вісник Харківського університету. Серія Психологія. 1999. Вип. 432. С. 91-97 
Initially, this was due to the congenital psycho-physiological differences between the sexes, but further research, in particular the transformation of female relationships into sexual fantasies due to changes in their rights and awareness in the field of sex, allowed to justify the view that this was more due to generally accepted stereotype of sexual relations, where the leading role was given to a man. It has thus been shown that the distinction between specific male and female sexual fantasies depends on the context in which they were perceived.

Homosexual imaginations are noted in individuals of both sexes about $7 \%$ of men and $11 \%$ of women. The same can be said about imaginations, when the subject fantasizes that he has been under sexual violence, or fantasies that despise the generally accepted social, moral or religious norms, for example, when a woman identifies herself with a prostitute or a harlot, and a man turns her in the object of "sexual exploitation". In the famous researches, Masters and Johnson ${ }^{19}$, studied a small sample of heterosexual, homosexual and bisexual women and men and found that the level of sexual fantasies was the lowest in bisexual men, and the highest in lesbians. Other studies have also shown that lesbians had usual woman as the main subject of sexual fantasies but in unusual situation, when heterosexual females often possessed a stranger in their fantasies. Heterosexual men usually build their fantasies around a particular woman, but not their usual partner. The most common theme of imagination for homosexual women and men is active coercion. Men fantasize about using physical power when lesbians often have psychological pressure.

It was found that sexual fantasies appeared in an extremely wide range of conditions and circumstances and could be either arbitrary or involuntary phenomena. Often, the sources of fantasies are well-known situations and events (for example, previously read book, movie or a real event): their content may vary depending on the situation, but the individual himself in all cases plays a major role. The nuclear or central masturbation fantasy is also important because it manifests itself in the

${ }^{19}$ Мастерс У., Джонсон В., Колодны Р. Мастерс и Джонсон о любви и сексе. В 2-х частях, часть 1 / пер. с англ. Н.М.Пивоваренок и др. Санкт-Петербург: СП "Ретур", 1991. 264 с. 
fact that the individual constantly fantasizes on the same topic, but there is no connection between the subjects and actors ${ }^{20}$.

In 2018, a survey of more than 4,000 men and women was presented by Justin Lehmiller, a psychiatrist at Harvard University ${ }^{21}$. According to it there were identified seven most common sexual fantasies. The rating has headed the sex of three and about $89 \%$ of the participants in the study informed about it. At the same time, respondents in relationships or marriage admitted that they would like to embody fantasy in life with the participation of their loved one. The second place got BDSM-practice (65\%). The top three was closed by sexual diversity: members in marriage or serious relationships noted that they were dreaming about sex with an unfamiliar person. The fourth place received the fantasy about sex in a public place. At the same time, women dreamed about this more often than men, wishing sex in an elevator, office or park. On the fifth position in the rating there appeared free relationships, in particular, the fantasy about sexing another person with the consent of the partner. In addition, $58 \%$ of respondents admitted that they were excited by fantasies about sex of their partner with another person. Homosexual sex rounded out the top list. According to J. Lehmiller, despite the fact that the participants in his study positioned themselves heterosexual, they often dreamed about lovemaking with a person of the same sex. In particular, 59\% of women admitted that they dreamed of having sex with a woman, while $26 \%$ of men reported that they had fantasies about sex with a man. They also fantasized about sex with transsexuals and transvestites.

In the same year, the results of studying the sexual fantasies among

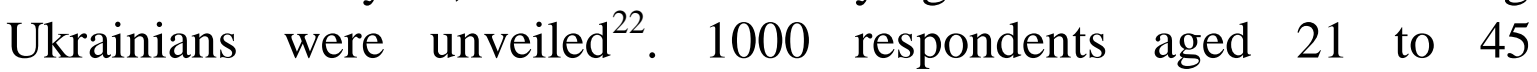
participated in the off-line survey. The focus group included young married couples, married for more than three years families, and young

20 Davidson K., Hoffman Sr. and Linda E. J. Sexual Fantasies and Sexual Satisfaction: An Empirical Analysis of Erotic Thought// The Journal of Sex Research Vol. 22, No. 2 (May, 1986), pp. 184-205.

${ }^{21}$ Young S. The seven most common sexual fantasies, revealed / Independent, 09/08/2018. URL: https://www.independent.co.uk/life-style/common-sexual-fantasiesthreesomes-bdsm-public-american-a8438566.html

${ }^{22}$ Сексологи назвали ТОП-7 эротических фантазий украинцев. Украина. Cosmopolitan. 2018. URL: https://www.cosmo.com.ua/seksologi-nazvali-top-7eroticheskih-fantaziy-ukraincev/ 
people without a permanent couple. Sexual fantasies were conventionally divided into two categories: "vanilla" - for embodiment of romantic and gentle desires of the partner, and BDSM - for fans to dominate and submit. From our point of view, this can be interpreted as a split of sexuality. The first category included the most common roleplaying game "student - teacher". A woman desired to live in luxury, to be a queen in her castle, and men - to please their beloved one. It built the basis for the emergence of "royal fantasy". And in turn, the wish of a woman to become better, to show superiority over competitors to her "sultan" formed the desire of Ukrainian couples to be in the harem. One of the brightest vanilla fantasies is the doctor's appointment. According to a study, about $50 \%$ of women get a spark from the idea of hard sex. It is also worth to note "gothic stories" with a reference to vampires and the film triumph "Twilight" among the varieties of the second category fantasies.

Until now, there is no single point of view on why some fantasies are the best and why people feel happy to come back to them. If in some cases all the charm of such a fantasy is the ability to make a person get pleasure from sexual excitement, then in other situations, one can become excited from the very role of "director", which is subject to everything: act, actors, and story, and it already indicates that fantasy is used as a means for solving other sexual difficulty. In many experiences, due to the complexity of such imagination, it is better to use it alone than during sexual intercourse with a partner. That is why it can be said that sexual fantasy has both positive and negative role in relation to normal development of personality by dissociating and eroticizing intrapersonal conflicts.

It is worth to note that the study of sexual fantasies by the Masters and Johnson Institute showed that most women, who were dreaming about unusual sexual practices such as rape, incest, sex with animals, sadomasochism would not want to endure such situations at all in reality. Unlike women, men were more courageous. About two-thirds of the respondents who had similar imaginations stated that they would not mind to live with certain circumstances.

The in-depth study by psychiatrists E. Hariton and J. Singer of the sexual fantasies among married women during sexual intercourse with their husbands showed that in fact most people with repetitive now and 
then fantasies did not feel the desire or the need to really experience them ${ }^{23}$.

Studies also show that for many people implementing sexual fantasies is unsatisfactory, as some "erotic" value of fantasy gets, however, almost completely lost.

Accordingly, the question of functions for sexual fantasies arises. The following functions are distinguished in the literature: 1) cognitive; 2) stimulating; 3) training; 4) creative; 5) compensatory; 6) replacing. And if the first four discrepancies are practically not observed, the consideration of the latter two puts a number of questions for the researchers, first of all, the question of why "a person is not very inclined to love, especially when he is making love."

In the Freud's thinking, sexual fantasies reflect the existence of a conflict between suppressed infantile impulses and family or social prohibition. Thus, they distort "normal sexual goals" along with other sexual perversions. Developing these ideas, R. Stoller believes that "daydreams in abridged form reflect the primary attitudes of the whole childhood and try to free people from frustrations, traumas and conflicts that took place in a childhood"24, and it gives them the opportunity to hurt the object of erotic fantasies at least in imagination. From his point of view, sexual fantasies of a man are his personal pornography, a revenge for suffering.

Avod Offit develops a slightly different approach. In his opinion, if reality and fantasy are in harmony with each other, then this indicates the "integrity of the individual" and psychological unity. If fantasy is too far from reality, then it points to potential psychological problems. Ultimately, A. Offit views sexual fantasies as "a miserable similarity to that complicated complex of joy and grief that is necessary for the love of a real person."

In a work entitled "Why We Should Not Perceive Sexual Fantasies," Bernard Apfelbaum defines imagination as "separate parts of

${ }^{23}$ Hariton E. B., Singer J. L. Women's fantasies during sexual intercourse: Normative and theoretical implications. Journal of Consulting and Clinical Psychology, 42(3), 1974. P. 313-322.

${ }^{24}$ Столлер Р.Дж. Перверсия: эротическая форма ненависти. / пер. с англ. С.Ф. Сироткина. Ижевск : ERGO, 2016. 220 с. 
us that signal about their desire to come back" ${ }^{\prime 25}$. He is convinced that sexual fantasies come from dissatisfaction with the existing reality and very often cause conflicts between partners. For example, if one of the partners sees that the reason for the sexual excitement of another is not he, but fantasy, then of course he feels disadvantaged and this emotion blocks his sexual response (although he admits that fantasy and attraction are different things). B. Apfelbaum also believes that if partners do not share their imaginations with each other, this reduces the trust and intimacy of relationships. According to him, "sexual fantasies always tell us what we need to do to strengthen our relationships".

\section{Structural features of pornocontent consumed by Ukrainian men}

PornHub is one of the largest (it will take one almost 1 million hours or 115 years to watch all 4.8 million videos) and the most popular (almost 92 million people access it every day, which is equal to the total population of Poland, Australia and Canada) porn site. According to its statistics during the 2018 Ukraine has risen to 11 places and ranked 16th, entering the top 20 countries, whose traffic accounts for up to $80 \%$ of Pornhub daily traffic (see Figure 1). Ukraine is on the 21 st place according to time spent on the site (see Figure 2), entering the top 5. Regarding this event, the site added a dash with an extensive analysis of the requests by Ukrainian users.

From a technological point of view, this is a global side effect of increasing the total number for online content consumers (in 2018, the site was visited 33.5 billion times). In addition, it must be understood that PornHub is not just a porn site, but an entire marketing corporation, which runs a fairly active legal advertising campaign with huge budget.

Unfortunately, the fact of Ukraine's entry into the top 20 was very actively used in the information hybrid war as an interpretation regarding the connection with the introduction for the 4-G technology early in the year (compared to 2017, the use of the smartphone for access to PornHub increased by $40 \%$, see Figure 3) and a variety of comparisons with Russia.

${ }^{25}$ Мастерс У., Джонсон В., Колодны Р. Мастерс и Джонсон о любви и сексе. В 2-х частях, часть 1 / пер. с англ. Н.М.Пивоваренок и др. Санкт-Петербург: СП "Ретур", 1991. 264 с. 


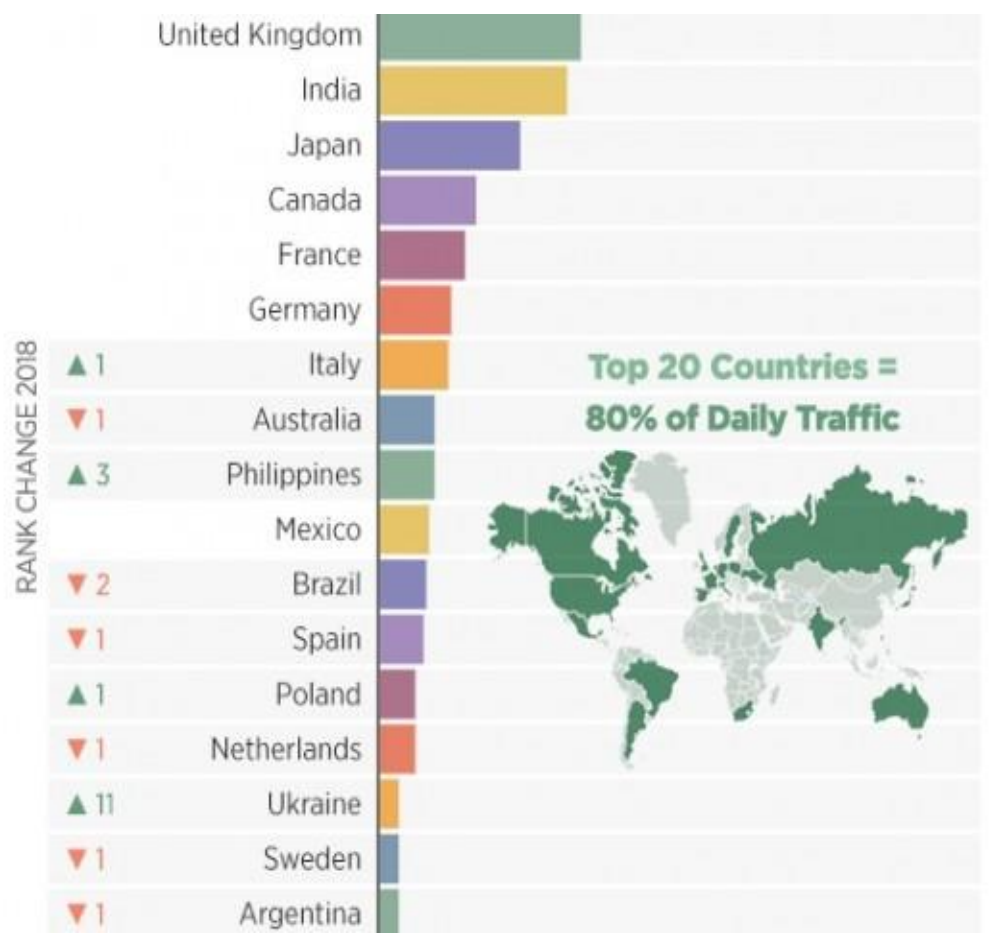

Fig. 1. Comparative rating of the host countries in PornHub traffic on the basis of 2018

\section{8}

\section{Time Spent Per Visit}

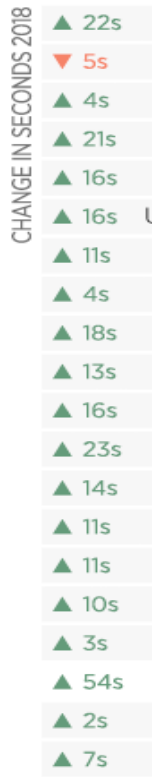

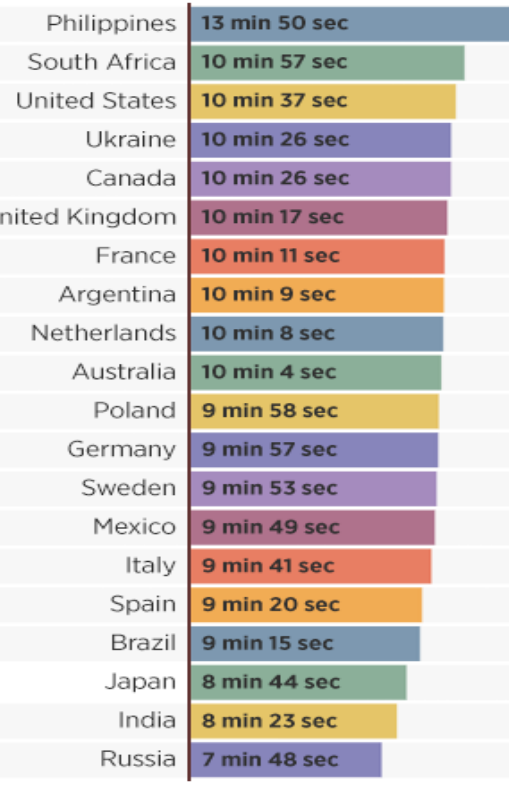

$10 \mathrm{~min} 13 \mathrm{sec}$

Average Visit Duration Worldwide 14 sec Increase in 2018

Largest Duration Increases of 2018 Czech Republic $\Delta$ 112s Algeria $\Delta \mathbf{8 0 s}$ Morocco $\triangle 56 \mathrm{~s}$ Sri Lanka $\Delta 55 \mathrm{~s}$ Japan $\Delta$ 54s Latvia $\Delta$ 50s $\mathrm{Fiji} \Delta 47 \mathrm{~s}$ Ethiopia $\Delta 52 \mathrm{~s}$ Moldova 4 40s Hong Kong $\Delta$ 37s

Fig. 2. Comparative analysis of the time spent on Pornhub according to results of 2018 


\section{8}

Traffic by Phone, Desktop \& Tablet

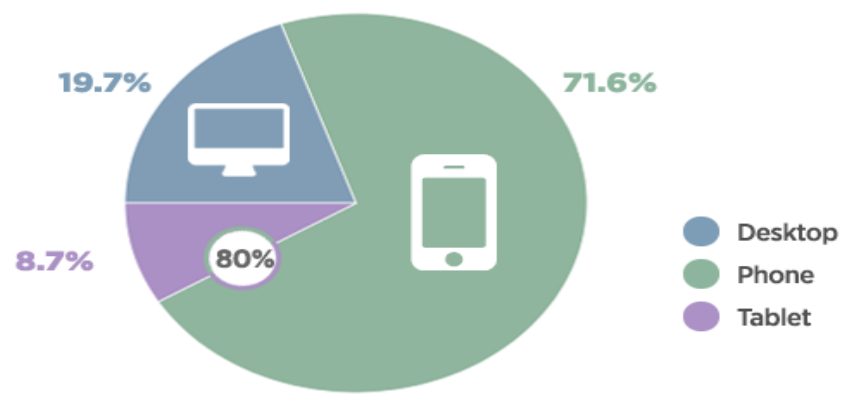

Change in Traffic Share from 2017 to 2018

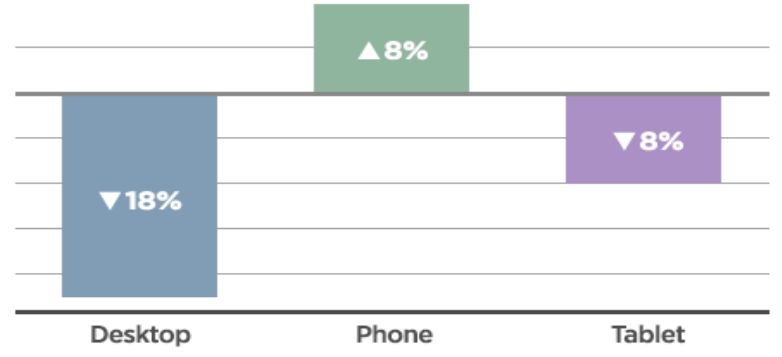

PORNHUB.COM/INSIGHTS

\section{Fig. 3. Comparative analysis of technological devices, using the PornHub content in the world of 2018}

Objective socio-psychological understanding of what exactly, why and whereto Ukrainian men (73\%) and women (27\%) are looking (gender distribution of users is present in Figure 4) during military aggression and rather complex political-economic transformations of society. In our opinion, it allows to highlight the psychological peculiarities and the underlying processes that take place in the area of gender and sexual changes towards digisexuality, which, unfortunately, remain without attention of researchers.

As you can see, the most commonly used words were "anime", "sex", "bdsm", "orgasm", "russian", and five most popular categories were "Hentai", "Milf", "Anal", "Cartoon", "Mature". The top looking at pornographic actors was recorded among Ukrainians and included popular Internet people who have already turned into memos - Alex Grey and Elsa Jean. For comparison, the world's most popular requests for 2018 were "Stormy Daniels" (largely due to the political scandal associated with US President Donald Trump), "Fortnite" (popular game), "4K", "Romantic", "Trans". 


\section{Pornhub}

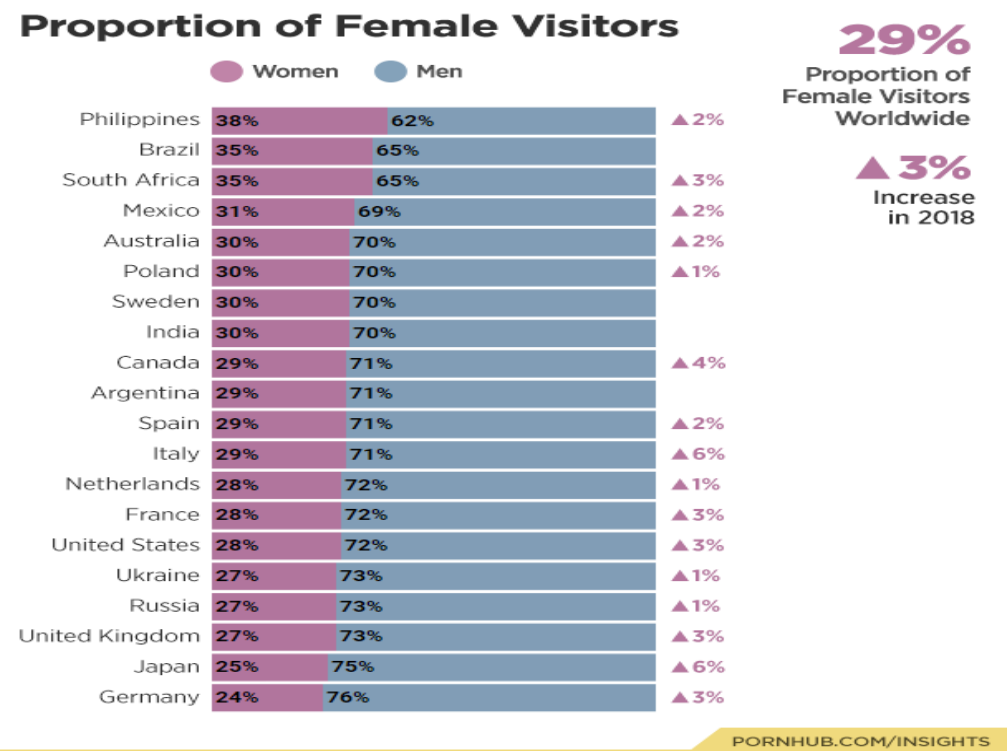

Fig. 4. Gender distribution of Pornhub traffic users in the world of 2018

Figure 5 shows a summary analysis of the requests by Ukrainian users.

\section{8 \\ Pornhub}

UKRAINE

Top Searches of 2018

$\Delta 40$

A 380

$\Delta 5$

4

$\mathbf{\nabla} 4$

A 12 hentai uncensored

> 3 step mom

$\nabla 6 \quad$ overwatch

A 56

$\nabla 4$

$\Delta 22$

Top Trending Searches

$$
\begin{aligned}
\text { anime } & \boldsymbol{\Delta} 367 \% \\
\text { pickup } & \boldsymbol{\Delta} 354 \% \\
\text { cuckold } & \boldsymbol{\Delta} 305 \% \\
\text { russian milf } & \boldsymbol{\Delta} 263 \% \\
\text { bdsm } & \boldsymbol{\Delta} 164 \% \\
\text { orgasm } & \boldsymbol{1} 156 \% \\
\text { blowjob } & \boldsymbol{\Delta} 121 \%
\end{aligned}
$$

Top 5 Pornstars

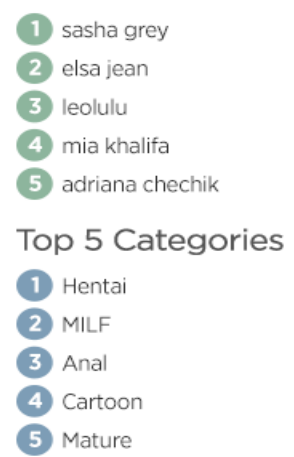

Top Relative Categories
(1) $\Delta 118 \%$ Fisting
(2) $\Delta 113 \%$ Hentai
(3) $\Delta 78 \%$ Cartoon
(4) $\Delta 67 \%$ School
(5) $\Delta 48 \%$ Bisexual

Fig. 5. Summary of searches by Ukrainian users of PornHub traffic in 2018 
To analyze the dynamics, we give data for 2016-2017 (see Figure 6).

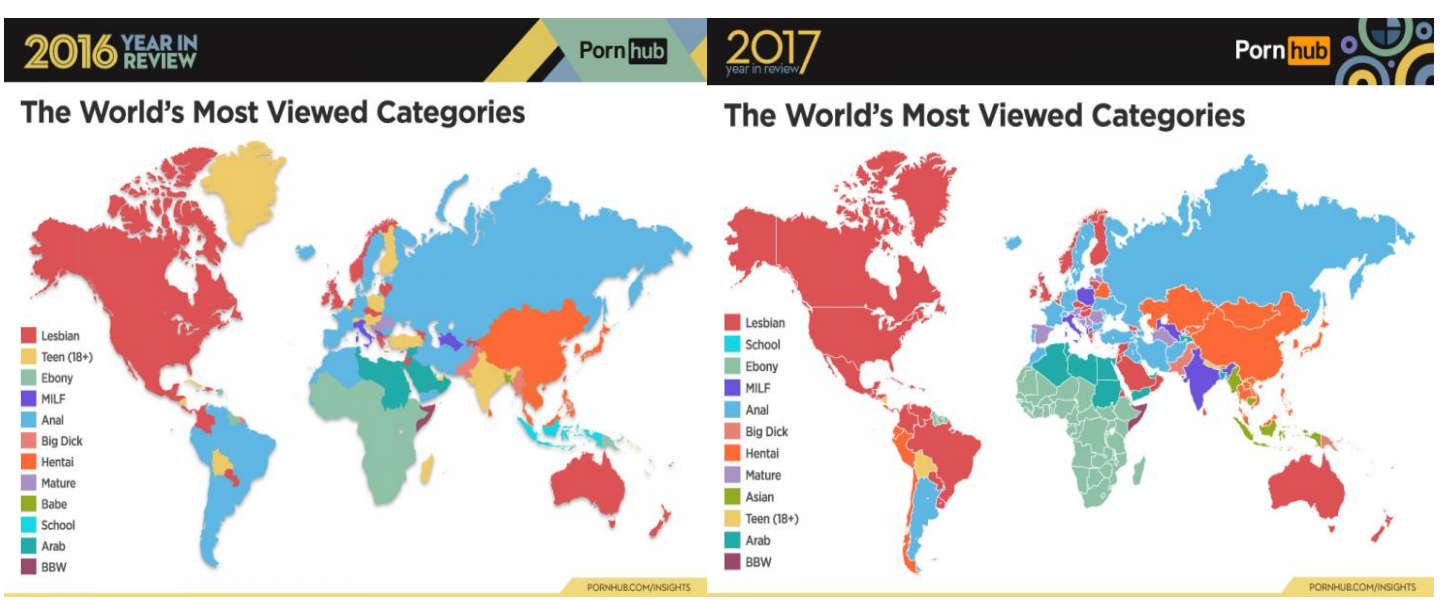

Fig. 6. Summary of PornHub most common requests among users in 2016-2017

As you can see, over the past three years, mature women and sexual practices of power and violence dominate in request. From our point of view, this is connected with the post-Soviet phenomena of "male inflation" 26 and general devaluation of maturity. Soviet culture, built on the patriarchal principle, placed men as the main carriers of psychological maturity. The sign of their maturation was the formation of a steady identification with a strong and mature father. This process began in 3-5 years and finally ended only in adolescence (when the formed identification was transferred to other male figures). Therefore, in order to enter the male (father) world, the boy also had to go through tough masculine filters (street company, place in the school hierarchy, various labor practices, "school of courage" - the army). Accordingly, guys who for various reasons could not be identified with their father or actively began to oppose him, turned into either outsiders or bandits. Today's Ukrainian society faces the fact that the father, as a strong figure, in most cases, is simply absent. Formerly, teenagers were involved in the interests of their parents, shared their values or rejected them. Nowadays, the problem of conflict between parents and children is weakened in proportion to the growth of the weakness of parents. The youth culture (included children and teenage "shadow" masculinity

${ }^{26}$ Уайли Дж. В поисках фаллоса: Приап и Инфляция мужского. СанктПетербург: БСК, 1996г. 128c. 
associated with the themes of castration and inflation) has become so powerful and wide spread. As a result, parents (adults) start to serve it (taking the form of clothing, the manner of communication, interests, etc.). Former, prosocial values of adult life are regarded as non-adaptive. But there appear on the foreground such inflation values as: rivalry, power, authority, aggression, etc. A boy quite simply gets a "social phallus" from the teenage environment, but loses the incentive for further maturation and the acquisition of "psychological phalos". Thus, we can talk not only about male inflation, but also about the devaluation of maturity - the absence or suppression of individual mature structures and meanings with external, behavioral, "adult" facade. Modern Ukrainian users of pornographic content want ambivalent mothers (who will love without dissecting and demands, but take an active, dominant sexual position) and cartoon characters (which solve their infantile conflicts using game and transient space by D.W.Winnikott).

\section{CONCLUSIONS}

1. The move of human sexuality into digital space is a global process that began in the 90's of the 20th century in connection with the development of technology and it has already passed several phases. It leads to qualitative and quantitative changes in the characteristics of sexuality (sometimes - very radical), which most researchers consider a fundamentally new form of sexuality - digisexuality. Ukrainian men from the patriarchal Soviet society are inevitably included in it at a pace that provides the level with development and affordability of technologies in the state for ordinary users.

2. Under unclear and contradictory state gender and cultural politics, digisexuality is not only an alternative, but also a competitor for the usual biosociopsychological sexuality. Combined with digital addiction, it leads to the simplification and / or lack of development (level of functioning) of psychological mechanisms for ensuring male sexuality (in particular, the areas of sexual fantasies), which is an integral part for the phenomenon of digital dementia. In addition, cybersexuality affects intimate interpersonal and marriage-family relationships, in the context of which the traditional biosociopsychological sexuality is realized.

3. One of the main instruments for digisexuality is such a marginal social and psychological phenomenon as on-line pornography. 
Analyzing the structure of pornographic content, we can identify both cultural taboo areas and those unconscious conflicts that occur in nondigital sexuality, that means a kind of generalized psychological portrait can be formed.

4. Analysis of sexual fantasies among Ukrainians shows that there is a certain split on the romantic and power component, which in our opinion reflects the presence of a large number of infantile aggressive fantasies and psychological difficulties for the establishment and support in deep, long, lasting, stable, and satisfactory relationships. The issue of destructive or constructive influence on this traditional pornographic (cinema, literature, etc.) and digisexual content remains open.

5. When analyzing the dynamics of request among Ukrainian men - users of the largest and most popular electronic porn resource named PornHub (in 2018, Ukraine ranked 16th among the states whose traffic occupies up to $80 \%$ of daily one) there was noted that period 2015-2018 showed the structure of male sexual interests which included paraggressive sexual practices (BDSM, anal sex, sexual betrayal in the presence of a family partner, etc.), images and plots associated with adult women (metaphorically - ambivalent mothers) and sex cartoons (milf, mature, cartoon, anime, etc.). From our point of view, this is connected with the post-Soviet phenomena of "male inflation" and the general devaluation of maturity, as well as the long-term prevalence of women's domination in education, training and family life, due to historical circumstances ("negative selection" of men). This is confirmed by already existing data on the male psychosexual formation in the relationship of marital coexistence. In this sense, digisex is the sexual orientation (in the broad sense) that supports and stimulates the infantile sexuality of Ukrainian men.

\section{SUMMARY}

The problem of transformation of male sexuality in the context of digital dementia was considered. The psychological differential and diagnostic criteria of dissociation between erotica and pornography, peculiarities in the digital world, their marginality as socialpsychological phenomena were demonstrated. There were discussed the special aspects of digisexuality and its connection with digital dependence. The statistics of modern national sexual fantasies and the destructive influence of porno content were analyzed. The structural 
features of sexuality among Ukrainian men, in particular the phenomena of male inflation and the devaluation of psychological maturity were revealed based on the statistics of requests by Ukrainian consumers at the largest electronic porn resource PornHub.

\section{REFERENCES}

1. Жидко М.Е. Сексуальные фантазии: гендерные, возрастные особенности и их взаимосвязь с психосексуальным поведением. Вісник Харківського університету. Серія Психологія. 1999. Вип. 432. С. 91-97

2. Журенков К. О дивный, новый секс! Цифросексуалы - кто они? Журнал «Огонек». 2017 № 51 C. 38. URL: https://www.kommersant.ru/doc/3501080 (дата звернення 15.03.2019).

3. Зимбардо Ф., Коломбе Н. Мужчина в отрыве: игры, порно и потеря идентичности. Москва: Альпина Паблишер, 2017. 344 с.

4. Калинина Е., Зонхоева Л. Секс будущего: что нас ждет в эпоху digital. URL: https://adindex.ru/publication/opinion/internet/ 2015/09/10/127814.phtml_(дата звернення 05.04.2019).

5. Кочарян А.С., Жидко М.Е. Психосексуальное развитие человека. Формирование мужского гендера. Харьков. НАУ «ХАИ», 2005. $91 \mathrm{c}$.

6. Курпатов А. Четвертая мировая война. Будущее уже рядом. Москва: Академия Смысла, 2018. 335 с.

7. Линден Д. Мозг и удовольствия. Москва: Эксмо, 2012. 288 с.

8. Мастерс У., Джонсон В., Колодны Р. Мастерс и Джонсон о любви и сексе. В 2 частях, часть 1 / пер. с англ. Н.М.Пивоваренок и др. Санкт-Петербург: СП "Ретур", 1991. 264 с.

9. Пази М. Цифровая любовь. «Русский репортер» 2019. № 3 (467) URL: https://expert.ru/russian_reporter/2019/03/tsifrovayalyubov/_(дата звернення 21.04.2019).

10. Полоролевая психология: коллективная монография / А.С. Кочарян и др. ; под ред. А.С. Кочаряна; Харьков: ХНУ им. В.Н. Каразина, 2015. 260 с.

11. Право, релігія, кіно / Д.О. Вовк та ін. ; за заг. ред.: Д.О. Вовк, О.П. Євсєєва. Харків: ТОВ «Видавництво „Права людини“», 2018. $184 \mathrm{c}$.

12. Сексологи назвали ТОП-7 эротических фантазий украинцев. Украина. Cosmopolitan. 2018. URL: https://www.cosmo.com.ua/ 
seksologi-nazvali-top-7-eroticheskih-fantaziy-ukraincev/ звернення 11.04.2019).

13. Смолл Г., Ворган Г. Мозг он-лайн. Человек в эпоху Интернета. Москва: КоЛибри, 2011. 352 с.

14. Столлер Р.Дж. Перверсия: эротическая форма ненависти. / пер. с англ. С.Ф. Сироткина. Ижевск : ERGO, 2016. 220 с.

15. Стрельникова Л. Цифровое слабоумие. Химия и жизнь. 2014.№ 12. URL: https://www.hij.ru/read/articles/view/5210/ (дата звернення 12.03.2019).

16. Уайли Дж. В поисках фаллоса: Приап и Инфляция мужского. Санкт-Петербург: БСК, 1996г. 128с.

17. Davidson K., Hoffman Sr. and Linda E. J. Sexual Fantasies and Sexual Satisfaction: An Empirical Analysis of Erotic Thought // The Journal of Sex Research Vol. 22, No. 2 (May, 1986), pp. 184-205

18. Cooper A., Safir M. P., Rosenmann A. Workplace worries: A preliminary look at online sexual activities at the office - emerging issues for clinicians and employers. Cyberpsychology \& Behavior 2006: 9:22-29

19. Hafner K. Laptop slides into bed in love triangle. The New York Times. August 24, 2006.

20. Hariton E.B., Singer J.L. Women's fantasies during sexual intercourse: Normative and theoretical implications. Journal of Consulting and Clinical Psychology, 42(3), 1974. P. 313-322.

21. Maltz W., Maltz L. The Porn Trap: The Essential Guide to Overcoming Problems Caused by Pornography. HarperCollins, New York. 2008

22. Nash, Catherine, Gorman-Murray, Andrew (Eds.) The Geographies of Digital Sexuality Palgrave. Macmillan, 2019. XV, p. 286

23. Spink A., Jansen B.J. Web Search: Public Searching of the Web. Berlin: Springer-Verlag, 2004

24. Tomas I. Digital sexuality: the Internet as an intermediary and mediator of sex / Blogs Wales Institute of Social \& Economic Research, Data \& Methods (WISERD) URL: https://blogs.cardiff.ac.uk/wiserd/ 2017/07/21/digital-sexuality-the-internet-as-an-intermediary-andmediator-of-sex/_(дата звернення 19.04.2019).

25 . Young S. Digisexuals: number of people who prefer sex with robots to surge, find experts / Independent, 30/10/2017. URL: https://www.independent.co.uk/life-style/digisexuals-robot-sex- 
preferences-university-manitoba-canada-identity-a8084096.html (дата звернення 10.04.2019).

26. Young S. The seven most common sexual fantasies, revealed / Independent, 09/08/2018. URL: https://www.independent.co.uk/lifestyle/common-sexual-fantasies-threesomes-bdsm-public-americana8438566.html (дата звернення 19.03.2019).

\section{Information about the author:} Zhydko M. E.

$\mathrm{PhD}$, Associate Professor, Head of the Psychology Department N. Ye. Zhukovskiy State Aerospace University "Kharkiv Aviation Institute" 17, Chkalov str., Kharkiv, 61085, Ukraine 